\title{
Selected Reference Books of 1964-1965
}

$\mathrm{T}$

HIS ARTICLE continues the semi-annual series ${ }^{1}$ originally edited by Constance $\mathrm{M}$. Winchell. Though it appears under a byline the list is actually a project of the reference department of the Columbia University libraries, and notes are signed with the initials of the individual staff members. ${ }^{2}$

Since the purpose of the list is to present a selection of recent scholarly and foreign works of interest to reference workers in university libraries it does not pretend to be either well balanced or comprehensive. Code numbers (such as A11, 1A26, 2S22) have been used to refer to titles in the Guide ${ }^{3}$ and its supplements.

\section{BIBLIOGRAPHY}

British Museum. Dept. of Printed Books. General Catalogue of Printed Books: Additions, 1963- . London: Trustees of the British Museum, 1964- . (1963 in 5v.) $84 s$ a yr.

In this first of the annual supplements which will list "entries added each year to the General Catalogue of Printed Books in the British Museum" (Pref.) most of the entries are of recent date, but there are, of course, many older imprints. No annuals for the years 1956-1962 (the gap now existing between the photolithographic edition of the Catalogue and the present publication) are planned, but a decennial cumulation of additions for 1956-1965 will eventually be issued so that the record will be complete. Style and format are those of the photolithographic edition.-R.K. 1952.

${ }^{1}$ CRL, January and July issues starting January

2 Carol Anne Bondhus, Marilyn Goldstein, Rita Keckeissen, Evelyn Lauer, Carol Learmont, Sarah Ropes, Charlotte Smith.

anstance M. Winchell, Guide to Reference Books (7th ed.; Chicago: ALA, 1951) ; Supplement (Chicago: ALA, 1954) ; Second Supplement (Chicago: ALA, 1956) : Third Supplement (Chicago: ALA, 1960) : Fourth Supplement (Chicago: ALA, 1963).
Musiker, Reuben. Guide to South African Reference Books. 4th rev. ed. Cape Town and Amsterdam: A. A. Balkema, 1965. $110 \mathrm{p}$.

Previously a mimeographed publication, the Guide in this fourth edition appears as a compact, well printed volume. Purpose and scope remain the same: to list the important reference works on South African topics, the selection being limited largely to books published in the Republic of South Africa. Arrangement of the work has been revised and improved, and most of the annotations have been rewritten or expanded. -E.S.

Musso Ambrosi, Luis Alberto. Bibliografía de bibliografías uruguayas. Montevideo: 1964. 102p. $\$ 3$.

This is a welcome addition to the relatively small group of well executed South American bibliographies. Compiled under the guidance of the director of the National Library, the work is a comprehensive overview of bibliographies published in or about Uruguay, from all periods of that country's history. Uruguayan government-published bibliographies are also included. Citations are arranged by subject field, and there is an author index. The editor hopes to continue the work through supplements.C.A.B.

Nachdruckverzeichnis von Einzelwerken, Serien und Zeitschriften aus allen Wissensgebieten (Reprints). Renate Ostwald, ed. Bd.1- . Wiesbaden: Nobis, 1965- . $\$ 25$.

Here is a kind of "books in print" for the burgeoning reprint trade. Reprint editions of books, journals, and other serial publications, regardless of method of reproduction, are included, and more than a hundred European and American publishers are represented. Arrangement is by author or other main entry, with cross references from editors, variant titles of journals, etc. 
Information includes original publication date when known, plus place, publisher, and (usually) date of the reprint. Series notes are given when applicable, and there is an appendix providing references from reprint series to the main entry. Although the editor felt obliged to omit prices, the work should be a great timesaver in both acquisitions and reference work. One hopes that it will appear on a regular basis.-E.S.

National Union Catalog: Register of Additional Locations. Washington, D.C.: Library of Congress, June 1965- . Included in NUC subscription.

To be published in a cumulative pattern, this new monthly supplement notes additional locations of titles included in earlier issues of the National Union Catalog reported after publication of annual or quinquennial cumulations. The first issue supplements the 1958/62 list and notes principally books represented by Library of Congress cards printed from 1956 through 1959. The Register contains two lists, the first (and considerably longer) by Library of Congress card number, the second by main entry. The latter represents titles submitted to National Union Catalog by other libraries. Coverage will increase with successive issues, and by 1968 is expected to be on a current basis. Together with $\mathrm{Na}$ tional Union Catalog 1952-1955 Imprints (Suppl. 4A12), this new publication greatly increases the scope of the National Union Catalog.-R.K.

\section{Book Reviews}

Book Review Index. Detroit: Gale Research, 1965- . v.1- . Monthly, cumulating quarterly. $\$ 24$.

Now that the Index to Book Reviews in the Humanities has been reduced to an annual, this new publication fills a gap, listing book reviews appearing in a wide range of current periodicals. More than two hundred English-language (mostly United States) periodicals of general circulation and specialized periodicals which have "substantial circulation among libraries, scholars, and others having a great interest in books" are indexed. Specialized scientific and technical periodicals are excluded. Arrangement is alphabetical by author of the book reviewed; citations include names of reviewers when known. The first cumulation listed thirteen thousand five hundred citations of nine thousand five hundred books; periodicals added since the first issue have been indexed retroactively through January. The great number of periodicals indexed, the short time lag involved, and the inclusion of books reviewed only once make this a practical, useful tool.-C.L.

\section{Publishing}

Publishers' World. Sally Wecksler, ed. New York: Bowker, 1965- . Annual. \$15.

Intended to provide a place for the exchange of information and ideas in international bookselling and publishing, this new yearbook contains much information valuable to librarians. Short articles in English or in French with English summaries are arranged under general headings, "About Best Sellers" being of special interest to librarians. Following these are sections containing facts and statistics, some of the more useful being: UNESCO standards for publishing statistics, international lists of libraries and the size of their holdings, international literary prizes, holidays in all countries, and an index to advertisers classified by country and subject. There is no general index, but the Contents are full and annotated. This is a handy yearbook, although somewhat expensive for its size (335p. in the 1965 volume).-S.R.

\section{DIRECTORY}

Unesco Handbook of International Exchanges. v.1- . Paris: UNESCO, 1965- . 861p. \$12.

Title and introductory matter also in French, Spanish and Russian.

Intended to provide "information on the aims, programmes and activities of national and international organizations, and on agreements concluded between States, concerning international relations and exchanges in the fields of education, science, culture and mass communication" (Introd.), this volume supersedes UNESCO's Directory of Cultural Relations Services (1959; Suppl. 4C5) and its Index of Cultural Agreements (1962). It includes information on 272 international organizations and about five thousand governmental and nongovern- 
mental agencies and institutions. Some information previously appearing in Study Abroad and Travel Abroad has been transferred to this new publication. The work is in three main parts: I, Introductory articles; II, International organizations: aims and activities; III, National organizations and activities. The latter section is arranged by country, with organizations grouped thereunder by field of interest. There is a country and organizational index.-E.S.

\section{Periodicals and Newspapers}

\section{Catalogue collectif belge et luxembourgeois} des périodiques étrangers en cours de publication, rédigé sous la direction de A. Cockx. . . . Brussels: Culture et Civilisation, 1965. 2v. $2.400 \mathrm{FB}$.

Title and introductory matter in French and Flemish.

Although it will have limited use (chiefly as a verification tool) even in very large American libraries, this first Belgian union list of serials in thirty years merits attention. It provides a finding list in libraries of Belgium and Luxemburg of periodicals currently published outside those areas. (Belgian publications are listed in Julien van Hove's Répertoire des périodiques paraissant en Belgique and its three supplements, Suppl. 1E6.) Scope and arrangement are carefully detailed in the introduction; American librarians will need to keep in mind that annual reports, bulletins, etc., are entered by title rather than under issuing body. Some four hundred libraries reported holdings, and the list of these forms a useful directory indicating accessibility, hours, and special services.-E.S.

U.S. Library of Congress. Slavic and Central European Division. Newspapers of East Central and Southeastern Europe in the Library of Congress. Robert G. Carlton, ed. Washington: 1965. 204p. \$1.

This guide to the Library of Congress collection of east central and southeast European newspapers published from 1918 to date is especially useful because of the very complete data on specific holdings. Both bound volumes and microfilm are included in an alphabetical arrangement by ceuntry, then by city of publication. Most entries also include information on frequency, date of establishment and the issuing body, publisher, or editor. Separate indexes for place of publication, language, and title make all the information readily available.-S.R.

Ulrich's International Periodicals Directory; a Classified Guide to a Selected List of Current Periodicals, Foreign and Domestic. 11th ed., ed. by Eileen C. Graves. New York: Bowker, 1965- . v.1- .\$15 per v.

Contents: v.1, Scientific, technical and medical. $484 \mathrm{p}$.

Publication of a new Ulrich's is always something of an event, and certain features of this new edition invite notice here. "International" has been added in the title to emphasize the broader scope of coverage: though limited to titles in Roman alphabet or with subtitles and abstracts in English, there is a greater inclusion of foreign titles than formerly. Some twelve thousand titles of scientific, technical, and medical periodicals are included in volume 1 . (The second volume, covering the arts, humanities, business and social sciences, is promised for publication in early 1966.) Arrangement follows that of the previous edition, with eight new subject classifications added. New appendixes offer a reprint of the "American Standard for Periodical Abbreviations" and a "Subject Guide to Abstracting and Indexing Services." There is also a list of periodicals which appeared in the tenth edition, but which are known to have ceased publication.-E.S.

\section{RELigion}

Møller-Christensen, Vilhelm and Jørgensen, K. E. Jordt. Encyclopedia of Bible Creatures. Trans. by Arne Unhjem. Philadelphia: Fortress Pr., 1965. 302p. \$6.75.

Originally published in Danish (Copenhagen, 1952), this work now appears in English translation with certain additions, and with most Bible quotations taken from the Revised Standard Version. Instead of a straight dictionary arrangement, the book is divided into sections on mammals, birds, insects, and fish, etc., with entries for individual species arranged alphabetically within sections. This arrangement, as well as the tone of the text itself, are conducive to casual reading, but the index with its 
entries for both popular and zoological names makes for easy reference use. In addition to general information on the individual species and ancient customs relating to them, attention is drawn to special characteristics which make the scriptural references particularly apt. Where called for, account is taken of disagreement among Biblical scholars regarding identification of the animal named.-E.S.

\section{HYMNOLOGY}

McDormand, Thomas Bruce and Crossman, Frederic S. Judson Concordance to Hymns. Valley Forge, Pa.: Judson Pr., 1965. 375p. $\$ 7.50$.

Almost two thousand four hundred hymns are indexed in this simply arranged concordance. The keyword of any line in a hymn can be looked up in the "Line Index" where a reference number guides the user to the first line of the hymn. From there the hymn can be found in the index of the user's hymnal. Hymns were selected from twenty-seven hymnals of major American and Canadian denominations, but no references are made to particular books. Clear instructions make this reference book very easy to use.-S.R.

\section{Social SCIENCES}

Congressional Quarterly Service. Congress and the Nation, 1945-1964; a Review of Government and Politics in the Postwar Years. Washington: 1965. 1784, 231p. $\$ 27.50$.

Congressional Quarterly Service here offers in one volume a comprehensive review of United States government and politics in the twenty postwar years. The CQ Almanacs served as the basis of the compilation, but additional material was derived from other reference sources. The major part of the volume treats chronologically every area of legislation with its background and political significance, the discussions often incorporating tables and charts. The second section comprises a directory of persons and events, with materials ranging from a biographical index to Congress for this period to a glossary of legislative terms. There is a detailed table of contents, an index, and a system of useful cross references. Well orga- nized, the book is news research in a refined form and is highly suited to quick reference and fact-finding needs.-M.G.

Lystad, Robert A., ed. The African World; a Survey of Social Research. New York: Praeger, 1965. 575p. $\$ 15$.

Prepared for students and scholars other than subject specialists, this review of recent and current social research studies and techniques in the African field includes each of the major areas touching man's social development-law, history, education, linguistics, etc. Eighteen social scientists contributed chapters on the state of research in their individual fields, reporting on achievements, theories, and trends in research, and indicating areas for future study. Students should benefit from the discussions of the technical aspects of the investigating methods, and certainly the excellent bibliography will be of value to those interested in African affairs.-C.A.B.

ReQua, Eloise G. and Statham, Jane. The Developing Nations; a Guide to Information Sources Concerning Their Economic, Political, Technical and Social Problems. Detroit: Gale Research, 1965. 339p. $\$ 8.75$. (Management Information Guide, 5.)

Largely a bibliography of "scholarly books, documents published by governments and international organizations, and articles appearing in a variety of journals" (Foreword), this guide includes only English language materials from the holdings of the Library of International Relations in Chicago. Though selective, the work should be very useful to both scholars and businessmen. Eight chapters cover special topics, and five list general reference sources, bibliographies, directories, and agencies and institutions administering development. Entries are annotated, and the work is indexed by author and title. It is an excellent guide to hitherto scattered and somewhat elusive information.-C.L.

Urquhart, M. C., ed. Historical Statistics of Canada. Cambridge: The University Pr.; Toronto: Macmillan, 1965. 672p. $\$ 15$.

Compiled under the joint sponsorship of the Social Science Research Council of Can- 
ada and the Canadian Political Science Association, this volume offers a wide range of statistical time series with descriptive information on Canadian economic, social, and political affairs. In general, the period covered is 1867-1960. Patterned after Historical Statistics of the United States, the work is divided into twenty-one subject areas, each commencing with notes on sources, derivations, and attributes of the data included; series of consecutively numbered tables then follow. Figures are taken generally from published sources, and are mostly annual and national in scope. The detailed table of contents and the comprehensive subject index aid in finding material quickly and easily. A pioneer work, this should be highly useful as a starting point for the research scholar interested in statistics for Canada, particularly in the area of the social sciences.-M.G.

\section{Abbreviations}

Kramer, Alex A. Abbreviations in Soviet Publications. Trenton, N.J.: Scientific Russian Translating Service, 1965. 396p. \$10.

Some nineteen thousand five hundred Russian abbreviations and acronyms are listed here with their full Russian components and English translations. Also included are the "meanings of various signs and symbols from the Greek and Latin alphabets used in the USSR." Although heavily weighted toward scientific and technical terms, this should prove a welcome supplement to a regular dictionary, particularly for those engaged in translation or dealing with contemporary Soviet affairs.-E.L.

\section{ENGLISH USAGE}

Bernstein, Theodore Menline. The Careful Writer; a Modern Guide to English Usage. New York: Atheneum, 1965. 487p. $\$ 7.95$.

Bernstein, a New York Times editor, has illustrated his new guide to good written English usage with examples drawn chiefly from newspapers. His aim is to promote coherent communication as well as originality and adroit phrasing: the result is delightful reading. In spite of a dictionary arrangement, the book lends itself to leisurely pe- rusal rather than quick reference. Articles such as "Atomic flyswatters" (on the American tendency to overemphasize) or "Lo, the poor idiom" (which appears under "L") would be hard to locate in a hurry, but they are useful discussions and cross references aid in finding them. The volume offers sensible advice on current usage.-S.R.

\section{LITERATURE}

American Literary Scholarship, 1963-

Ed. by James Woodress. Durham, No.

Car.: Duke Univ. Pr., 1965- . Annual. \$6.

Seventeen scholars have contributed bibliographical essays on American literature to this first volume of a proposed annual survey similar to The Year's Work in English Studies. The new annual obviously allows for more detailed coverage than the single chapter allotted to American literature in The Year's Work, though the contributors were permitted to choose between selectivity and inclusiveness: "Some have preferred to cover as much ground as possible, discussing many articles and books briefly; others have reviewed in more detail only the items regarded as the most important" (Foreword). The first eight essays treat of major individual authors or pairs of authors; the others deal with American literature to 1800 , fiction and poetry by period, the drama, and a miscellaneous section. Some chapters include citations to earlier publications, but for the most part discussion is confined to those of 1963 . This deserves to become an established series; it also deserves - even requires-the addition of an index in future volumes.-E.S.

Balášová, Olga. Bibliografie české literární védy, 1945-1955; práce o české literatuře.

Praha: Státní pedagogické-nakl., 1964. 692p. 33 kes.

Czech works dealing with Czech literary history and criticism are listed here in two general sections. The first section lists books and articles on literary theory (e.g., aesthetics, criticism, translation) while the second is devoted to items concerning literary history. The balance of the work, and by far the largest part of it, consists of bibliographies arranged alphabetically by names of the authors about whom the items are 
written. A chronological survey of authors, a personal name index of authors as subjects, and an author index for the writers of the critical works complete the volume. It is to be hoped that this guide will be continued for other decades.-E.L.

Bateson, Frederick Wilse. A Guide to English Literature. Garden City, N.Y.: Anchor Books; Chicago: Aldine Pr., 1965. 258p. \$1.25 paper; \$5 cloth.

Designed as "a bibliographic labor-saving device," this guide "lists the editions and commentaries to go to first" (Pref.). Individual authors and works of literature, as well as general books about the literature, are treated, and the coverage is wider than the size of the volume would indicate. Arrangement is chronological by four main periods (Medieval, Renaissance, Augustan, and Romantic) with additional chapters for literary criticism and research. Before each of the period sections is an interchapter which serves as a brief but scholarly introduction to the period. The period sections consist of reading lists in essay form covering materials through 1963, with some 1964 titles. These lists are not conducive to quick checking, and the brief index is little help in this matter. That, however, is a minor flaw, and students will find the work a useful companion to the Cambridge Bibliography of English Literature.-C.S.

Kunisch, Hermann. Handbuch der deutschen Gegenwartsliteratur. München: Nymphenburger Verlagshandlung, 1965. 781 p. $\$ 17.70$.

The purpose of this work is to present a compact guide to contemporary German literature and literary criticism. It includes poets, novelists, dramatists, critics, scholars, publishers, and cultural innovators, especially if their influence has been widespread. The volume is divided into two parts, the first and most sizable being alphabetically arranged articles on individual authors and their works, together with author bibliographies and citations to selected works of criticism. The second part is a collection of scholarly essays on such diverse subjects as Expressionism, German literature in exile, 1933-1947, poets and poetry of $\mathrm{Na}$ tional Socialism. A detailed name index makes all references to a given person immediately accessible, whether described in a separate article or in one of the essays.E.L.

\section{Wilgat, Janina. Literatura polska $w$ świecie;} bibliografia przekładów, 1945-1961. Warszawa: Penclub, 1965. 286p. zk. 60.

Nearly twenty three hundred items are listed in this bibliography of translations into other languages of Polish literary writings. Entry is by author, with a special section of anthologies arranged by language. There is an index of translators and editors of anthologies, as well as a geographical index which enables the user to identify the translations published in each of some forty countries.-E.S.

\section{Drama}

Cumulated Dramatic Index, 1909-1949; a Cumulation of the F. W. Faxon Company's Dramatic Index. . . . Boston: G. K. Hall, 1965. 2v. \$490.

Like the Cumulated Magazine Subject Index recently noted in these pages, this publication provides easy access to contents of a long series of annual volumes not previously cumulated. Entries from the original forty-one annual volumes of the Dramatic Index (Guide R135) have been interfiled under uniform headings in the main body of the work, and each of the three appendixes (author list of books about the drama; title list of published play texts; Author list of published play texts) has been cumulated also. The resulting convenience to researchers and librarians is obvious and welcome.-E.S.

\section{BIOGRAPHY}

Who's Who in Europe; Dictionnaire biographique des personnalités européennes contemporaines. Ed. by Edward A. DeMaeyer. Ed. 1- , 1964/65- . Bruxelles: Editions de Jeniks, 1965- : 2680 p. $\$ 40$.

Too limited in coverage to serve the small library as an all-purpose biographical dictionary for Europe, this work may have some value in the large reference collection, chiefly for its listings of personalities from small European states such as Andorra and San Marino which do not appear in the 
standard "who's whos." Only twenty-five countries and states are represented, all except Turkey being in western Europe. Biographees represent most professions and industries; entries are fairly standard, with rather more space allotted to hobbies and memberships in social clubs than is the case in most works of this kind.-C.S.

\section{History}

Belder, J. de and Hanes, J. Bibliographie de lhistoire de Belgique, 1865-1914. Louvain: Nauwelaerts, 1965. 301p. (Centre interuniversitaire d'histoire contemporaine. Cahiers, 38.)

This volume continues the sequence begun with Paul Gérin's bibliography for the period, 1789-1831 (Suppl. 4V91). (A volume by S. Vervaeck covering the intervening period, 1831-1865, is announced as no. 37 in the series, but has not been received at this writing.) As with the Gérin work, this bibliography covers all aspects of Belgian history and follows the classed arrangement with author and subject indexes. Official publications and biographical works are largely omitted in view of existing bibliographies of these materials in the Cahiers series.-E.S.

Chandler, M. J. A Guide to Records in Barbados. Oxford: publ. for the University of the West Indies by Blackwell, 1965. 204p. 63 s.

The department of history of the University of the West Indies, aided by the Rockefeller Foundation, is undertaking a survey of records of the English-speaking Caribbean territories. This first volume to be published lists and briefly describes various collections in Barbados as they existed in 1961. Records are classified as those of central government, local government, semipublic, ecclesiastical, private, and manuscript collections. Within classes, records are listed by repository, and the entries include useful historical notes on the various departments and agencies responsible for the record-keeping. This, and the other volumes promised, should provide the key to large resources of primary materials for historians and other scholars working in this area.-C.L.
Commission Internationale pour l'Enseignement de l'Histoire. Les deux guerres mondiales; bibliographie sélective. Bruxelles: Editions Brepols, 1965. 246p. \$9.

Added title-page: The two world wars. . . L London, New York: Pergamon Pr., 1965.

The editors note that this is a selective bibliography, the purpose of which is to act as a guide for history teachers. Of the $\mathbf{2 4 6}$ pages in the book, however, only a mere eighty are given over to actual bibliography, the rest consisting of a long background article on "July 1914" with a French résumé, and two introductory articles in both French and English. The bibliographies (separate ones for each of the two World Wars and for the interwar period) are annotated in French and English. Altogether they list about a thousand titles in classed arrangements which include documents, monographs, bibliographies, and collections of principal photographic and film libraries. A serious omission is that of an index.-E.L.

Fuentes, Jordi and Cortés, Lía. Diccionario histórico de Chile. Santiago de Chile: Editorial del Pacifico, 1965. 329, [35]p. $\$ 12.50$.

Although the articles in this new dictionary run heavily to biographical materials, there are numerous entries for political events and organizations, historic sites, and significant battles in Chilean history. The whole range of the country's history is covered. An asterisk serves as a see reference to alternate form of an entry, and as a see also reference within articles. There is a four-page bibliography at the end of the volume, but bibliographies are not provided with individual articles.-E.S.

News Dictionary, 1964- . New York: Facts on File, 1965- . Annual. \$6.75.

Designed as an "inexpensive reference work ... . for those who lack immediate access to other research services or the time to use them" (Pref.), this could be a useful desk-reference tool for the student or the small library; existence of the many other yearbooks and news services limits its usefulness for the large reference collection. In this first volume the major news events of 
1964, the workings of international organizations, and selected topics such as sports and education are covered-some quite extensively. Since certain of the articles are over twenty pages long, an index should have been provided for easier access to facts and dates, even though the arrangement is alphabetical and cross references are liberal. -C.S.

Wainwright, M. D. and Matthews, Noel. A Guide to Western Manuscripts and Documents in the British Isles Relating to South and South East Asia. New York, London: Oxford University Pr., 1965. 532p. \$16.

This is an extensive guide listing European language manuscripts "bearing on the whole of Southern Asia" that are contained "in all libraries, depositories and collections, public and private, in Great Britain and Ireland" (Pref.) with the exception of the India Office library. Subject coverage is allembracing, including history, literature, science, social science, and humanities. The information was compiled from catalogs, calendars, indexes (whether published or in manuscript), from information given by archivists and librarians, and from personal inspection of documents. Short descriptions are given for materials which are listed chronologically in appropriate subdivisions under the depository entry which, in turn, is found in a topographical arrangement. A full index of names and subjects draws together all items pertaining to one topic.R.K.

\section{STATISTICS AND STANDARDS}

(Continued from page 22)

Oboler, E. "Library Statistics: Why, How, and Maybe." Idaho Librarian, XIV (January 1962), 6-8.

Reichmann, Felix. "Management and Operations." Library Trends, III (April 1955), 462-70.

Rothstein, Samuel. "The Measurement and Evaluation of Reference Service," $\mathrm{Li}$ brary Trends, XII (January 1964), 45672.

Skipper, James E. "The Present State and Future Development of Technical Services," Library Resources and Technical Services, VI (Summer 1962), 205-9.

Wilson, Louis Round and Maurice F. Tauber. The University Library ( $2 \mathrm{~d}$ ed.) New York: Columbia University Press, 1956. p. 212.

\section{STATISTICS AND GLOSSARIES}

Association of Research Libraries. Academic
Library Statistics, 1963/64- . Washington, D. C.: The Association, 1964.

Canada. Dominion Bureau of Statistics. Education Division. Survey of Libraries, Part II: Academic Libraries, 1960/61. Ottawa, Queens Printer, 1963.

U. S. Office of Education. Library Statistics of Colleges and Universities, 1962-63. Institutional Data. Washington: 1964.

Vocabularium Bibliothecarii. Paris: UNESCO, 1962.

ALA Glossary of Library Terms. Chicago: American Library Association, 1943.

The Bowker Annual of Library and Book Trade Information. New York: R. R. Bowker Company, 1963.

The Bookman's Glossary. New York: R. R. Bowker Company, 1951.

Bibliographer's Glossary of Foreign Words and Phrases. New York: R. R. Bowker Company, 1933. 